\title{
What is Educational Entrepreneurship? Strategic Action, Temporality, and the Expansion of US Higher Education
}

\author{
Alexander T. Kindel ${ }^{1}$ \\ Mitchell L. Stevens ${ }^{2}$ \\ 1. Department of Sociology, Princeton University (akindel@princeton.edu) \\ 2. Graduate School of Education, Stanford University (stevens4@stanford.edu)
}

Forthcoming, Theory and Society

25 January 2021

Word count: 13,537

Keywords: entrepreneurship; strategic action; field theory; history of US higher education; engineering education

Acknowledgements: Previous versions of this paper benefited from multiple audiences at Princeton University and Stanford University, and at meetings of the American Sociological Association, the Social Science History Association, and the Society for the Advancement of Socio-Economics. We thank Elizabeth Armstrong, Steven Brint, Christina Groeger, Laura Hamilton, Michelle Jackson, Emily Levine, two anonymous reviewers and the editors of Theory $\&$ Society for comments that substantially improved our theorization. The first author gratefully acknowledges funding support from a National Science Foundation Graduate Research Fellowship. 


\title{
What is Educational Entrepreneurship? Strategic Action, Temporality, and the Expansion of US Higher Education
}

\begin{abstract}
The massive expansion of US higher education after World War II is a sociological puzzle: a spectacular feat of state capacity-building in a highly federated polity. Prior scholarship names academic leaders as key drivers of this expansion, yet the conditions for the possibility and fate of their activity remain under-specified. We fill this gap by theorizing what Randall Collins first called educational entrepreneurship as a special kind of strategic action in the US polity. We argue that the cultural authority and organizational centrality of universities in the US national context combine with historical contingency to episodically produce conditions under which academic credentials can be made viable solutions to social problems. We put our theorization to the test by revisiting and extending a paradigmatic case: the expansion of engineering education at Stanford University between 1945 and 1969. Invoking several contemporaneous and subsequent cases, we demonstrate the promise of theorizing educational expansion as an outcome of strategic action by specifically located actors over time.
\end{abstract}




\section{What is Educational Entrepreneurship? Strategic Action, Temporality, and the Expansion of US Higher Education}

In the days leading up to 4 October 1957, Stanford University Provost Frederick Terman was preparing a lunchtime talk for the Stanford Faculty Club. He had been asked to speak on a topic of growing public interest: a shortage of scientists and engineers trained to bolster national defense. Terman, an electrical engineering luminary with decades of expertise in engineering education, would dismiss the problem. ${ }^{1}$ His frequently expressed public view was that US engineering capacity would best be enhanced not by increasing the overall number of engineers; he believed there were plenty. Instead, he advocated taking the engineering professions "back to science:" replacing what he saw as narrow practical skills with the abstract tools of statistics and physics. ${ }^{2}$ On index cards outlining his oft-repeated statements on the subject, he wrote: "My thesis is that all these reports implying inadequate supply to get work done which can be performed only by engineers are greatly exaggerated. I can find no evidence...[t]hat defense is really suffering." ${ }^{.3}$ Though Terman's remarks were not exactly fresh, their timing would ultimately prove uncanny. Midday on 4 October 1957, the Soviet Union successfully launched Sputnik 1 into Earth's orbit. ${ }^{4}$

Terman's public position on engineering education for national defense shifted over the subsequent days. On 17 October, he described the Sputnik launch to Stanford's board of trustees

\footnotetext{
1 Terman, Frederick E. 1927. "The Electrical Engineering Research Situation in the American Universities." Science 65(1686): 385-388. For a biographical overview of Terman's professional career, see McMahon, A. Michal. (1984), The Making of a Profession: A Century of Electrical Engineering in America. New York: IEEE Press, Chapter 6 ("The New World of Electronics Engineering", p. 175-212).

${ }^{2}$ Terman, Frederick E. 1956. "Electrical engineers are going back to science!" Proceedings of the IRE 44(6): 738-740.

${ }^{3}$ F.E. Terman, notes for a talk at the Stanford Faculty Club, 4 October 1957; Folder 1, Box 2, Series VIII, SUA SC 160. Terman frequently gave speeches from handwritten outlines on index cards, rather than prepared texts; it is difficult to determine exactly what he said.

${ }^{4}$ Terman was scheduled to speak at lunchtime; Sputnik 1 officially launched at 19:28:34 UTC, or 12:28 pm PST.
} 
as "one of the great scientific achievements of all time," a historic moment that "dramatized our not too satisfactory situation" in matters of science and engineering capacity. ${ }^{5}$ By the following July, in remarks given to the Institute of Aeronautical Sciences, Terman was advocating engineering education as a solution for the nation's post-Sputnik problems:

The launching by the Russians of Sputnik I added fuel to discussions on education and increased vastly the audience listening to them .... If we are going to beat out the Russians in this technological race in which we are now engaged, or if we are even to hold our own with them, this will be largely because of the efforts of engineers and scientists who achieved high standards as undergraduate students, and then went to study further in the graduate program of one of our universities. ${ }^{6}$

Sputnik marked a turning point in Terman's career and in Stanford's fortunes as a university. Historians credit Terman with transforming Stanford in the decades following World War II from its origins as a lackluster rural university on the far side of a vast frontier into a global scientific powerhouse and a privileged servant of Washington, DC (Geiger 1993; Saxenian 1996; Lowen 1997; O’Mara 2005). In 1979, sociologist Randall Collins coined the term "educational entrepreneur" to describe people like Terman: academic leaders who sought to expand the functions, funding, and prestige of their own institutions (Collins 2019 [1979]). Subsequent educational sociologists elaborated on this imagery of academic leaders aggrandizing

\footnotetext{
${ }^{5}$ F.E. Terman, notes for a meeting with the Board of Trustees, 17 October 1957; Folder 1, Box 2, Series VIII, SUA SC 160 .

${ }^{6}$ F.E. Terman, "Some Observations on Engineering Education," prepared speech for the Institute of Aeronautical Sciences, 8 July 1958. Folder 2 Box 2 Series VIII SUA SC 160.
} 
their own schools, naming it as a mechanism of US postsecondary expansion (e.g. Brint \& Karabel 1989; Brown 1995; Labaree 2018; Trow 1988).

This imagery of individuals and their actions as causal drivers of large-scale institutional change is exceptional in a discipline constitutionally skeptical of individual-level explanations. The scale of US postsecondary massification after World War II is no modest side note to social change in the twentieth century. Summing to what Jencks and Riesman (1967) called an “academic revolution," the postwar decades witnessed a transformation of universities and the credentials they purvey into primary mechanisms for distributing opportunity, life chances and status honor in American society (Hout 2006, 2012; Torche 2011; Brint 2018). The exceptional credit sociologists have lent to individual actors in US postsecondary expansion is thus an intellectual opportunity, offering occasion to elaborate theory on how specific people and particular situations are implicated in larger processes of social change. We exploit that opportunity here. Integrating insights from organizational theory and historical sociology, we theorize educational entrepreneurship as a special kind of strategic action.

Organizational theorists define action as "strategic" when actors self-consciously leverage their social positions to accrete power, especially by influencing other actors (Fligstein 1997; Martin 2003; Fligstein \& McAdam 2012). Locations at the interstices of multiple organizational domains are fertile sites for strategic action. In multivocal social situations, actors can accrue power by recombining personal connections and organizational templates from multiple sources (Clemens 1993; Armstrong \& Bernstein 2008; Padgett \& Powell 2012). Sociologists of higher education add that universities are institutional "hubs" that manage flows of personnel and purposes between state, market, civil society, and private life (Stevens, Armstrong \& Arum 2008; Owen-Smith 2018). Organizational centrality makes universities 
peculiarly potent social mechanisms, capable of aligning interests across otherwise distant or even conflicting institutional domains.

Unlike actors elsewhere, educational entrepreneurs have a special cultural tool at their disposal. Schools are endowed with what John Meyer (1970) called the "charter": a near-exclusive normative license to certify official knowledge and confer it to others. The charter is a powerful tool for strategic action because it enables academic actors to define exchange relationships with myriad parties in academic terms, an accounting vocabulary that belongs especially to schools. To the extent that they can define problems in ways that make knowledge creation and formal training seem like solutions, academic actors are well-positioned to leverage the contingencies of history to further their own ambitions and the fortunes of the organizations they serve.

Drawing on historical sociologists' insights on the cultural dynamics of eventful times (Sewell 1996; Clemens 2007, 2015), we argue that contingent events create fertile conditions for educational entrepreneurship. When events disrupt established social arrangements, the search for solutions to new problems creates ready audiences and patrons for educational entrepreneurship. At such times, academics have opportunities to catalyze educational expansion. Observing how particular academic actors respond to historical ruptures and crises is essential for understanding the mechanics of educational entrepreneurship and, by extension, the ongoing evolution of US higher education.

Educational entrepreneurship was not a new phenomenon in the fall of 1957. Before then generations of academic leaders had used the charter to secure patronage from religious denominations, regional boosters, state legislatures and, episodically, the US federal government. In exchange, schools helped to solidify the cultural authority of a transatlantic educational elite 
(Bledstein 1976; Levine 2016) and extend US settlement across a growing Western frontier (Story 1980; Thelin 2011). In Terman's time, the legacy of World War II and the growing public authority of science in the US catalyzed a new wave of educational entrepreneurship. As we will show below, the federal government's efforts to respond to the Sputnik launch enabled Terman and his colleagues to define government patronage of elite science and engineering education as a plausible solution to newly pressing national problems. Similarly situated actors nationwide leveraged their interstitial positions and the charter to elicit vast new patronage for academic research and training. Herein, we argue, lie the conditions that explain how myriad acts of educational entrepreneurship produced the largest postsecondary education system theretofore in world history.

We develop our theorization by revisiting the expansion of Stanford's School of Engineering between 1954 and 1969. This case is useful for theory-building in part due to its paradigmatic status in the political history of Cold War science (on the methodological uses of paradigmatic cases, see Martin 2003; Creager, Lunbeck \& Wise 2007; Guggenheim \& Krause 2012; Ermakoff 2014). Although Stanford as an organization is by no means representative of postsecondary expansion writ large, its extreme transit across the status order of US higher education makes it invaluable for studying how, when, and where educational entrepreneurship works. Augmenting secondary literature with original archival research, we show that Stanford's leaders pursued greater influence and prestige for their own university by experimenting with a broader range of instructional offerings in applied science and engineering and securing financial support for these programs from a range of funders.

Although the Stanford case is an exceptionally rich source of detail, focusing on just one case might risk understating the prevalence and variety of educational entrepreneurship in the 
postsecondary sector as a whole, particularly those cases that present-day observers might deem to be less successful cases. After elaborating on Terman's efforts at length, we consider comparably ambitious academic leaders at other schools working at the same time, but under different local conditions. These additional examples enable us to portray how the educational entrepreneurs that drove postsecondary massification after World War II worked within, and sometimes against, their local, national, and world-historical context to grow their own organizations.

Doing this work is important not only to better understand what happened to US higher education during Terman's time, but also to appreciate the variable conditions under which those who seek to expand educational opportunities do their work into the present. In subsequent decades there has been no shortage either of calls for more accessible and affordable higher education (Goldrick-Rab 2016), or of ambitious people and organizations eager to provide it (Scott \& Kirst 2017; Cottom 2018). A working theory of how events, context, and agency combine to produce academic expansion can inform educational advocacy and policy-making in our own time.

Our work proceeds as follows. We first review inherited sociological explanations of US higher education expansion, noting a consistent recognition of educational entrepreneurship as a causal driver but thin theorization of its conditions and mechanics. Next we draw on organizational and historical sociology to theorize educational entrepreneurship as a special kind of strategic action Turning to our case study, we show how Stanford leaders took advantage of their interstitiality in the post-WWII research economy to build a lucrative portfolio of training programs that came to be defined as essential to national defense. We then compare the accomplishments of Stanford leaders with those of educational entrepreneurs working in other 
temporal and geographic contexts. We conclude by contrasting current circumstances for educational entrepreneurship with what obtained in Terman's day.

\section{Inherited Accounts of US Postsecondary Expansion}

Since the earliest days of the Republic, Americans have built schools to pursue a wide range of goals: to further religious identity and conversion, foster responsible citizenship, hasten the abolition of slavery, dominate indigenous peoples, and exert definitional control over frontier geographies (e.g., Kaestle 1983; Neem 2017). Early colleges served these endeavors by training teachers and ministers, providing civic infrastructure and signaling regional ambition. As the western frontier expanded, thriving colleges were signs that their places bore promise for further settlement and prosperity (Brown 2001; Thelin 2011). US school-building has been a diffuse activity, undertaken by a plurality of groups with partial, uneven patronage from state legislatures and only episodic involvement from the federal government.

Higher education became an organizational sector distinct from K12 schooling between the close of the Civil War and World War I. While reformers gradually succeeded in weaving a heterogeneous population of elementary and secondary schools into more or less coherent regional and state systems (Steffes 2012; Tyack 1974), individual colleges and universities retained substantial autonomy from one another, and from the state, even when they enjoyed tax exemption and other public subsidy. They did this partly by defining their identities as servants of particular religious denominations, cities and regions; partly by remaining ecumenical in patronage; and partly by distinguishing themselves as contributors to adult civil society rather than as nurturers of children (Mclachlan 1970; Wechsler 1977). 
Given the ubiquity and sheer number of organizations in the national postsecondary academic ecology, college leaders were continually on the lookout for new constituents and forms of revenue. One strategy was to tie pursuit of higher education to ideals of masculinity and ethno-racial privilege by accreting the ideal of "the college man" (Clark 2010). Colleges' embrace of football in the late nineteenth century was an important part of this strategy (Lifschitz, Sauder and Stevens 2014). Another was academics' successful collusion with elites in the nascent legal and allopathic medical professions to heighten requirements for occupational entry. Obliging aspiring lawyers and physicians to obtain bachelor's diplomas before graduate training boosted the prestige of these occupations while assuring demand for serial academic credentials (Starr 1982; Abbott 1988; Abel 1991). It also enabled a handful schools to claim the status of true universities: supporting basic collegiate instruction but also advanced research in a variety of specialized fields (Menand 2010; Levine 2016).

These phenomena received sustained attention from sociologists and historians from the 1960s forward, who leveraged historical priors to understand the growing prominence of higher education in US society in the decades following World War II (Abbott 1988; Bledstein 1976; Brint \& Karabel 1989; Jencks \& Riesman 1968; Levine 1986). Their work continued to recognize the causal importance of particular historical actors. Collins called these actors educational entrepreneurs: the canny, ambitious, and often competitive people who founded schools, devised new instructional programs and certifications, and courted heterogeneous clients and patrons (1979:119-120). In their germinal study of community colleges, Brint \& Karabel (1989) found educational entrepreneurs all over the county, assembling local resources and political will to found a whole new universe of publicly funded postsecondary schools. Consonant with a capacious historical literature depicting a dispersed and geographically varied 
postsecondary expansion (e.g. Veysey 1966; Rudolph 1990; Geiger 1993; Thelin 2011; Loss 2012; Groeger forthcoming), sociological accounts by Brown (2001) and Labaree (2017) similarly imply the causal importance of individual actors.

Yet this agentic imagery fits awkwardly into the larger theoretical architectures of educational sociology, which posit various macro-level processes as the causal drivers of expansion: the transition from a manufacturing to a service economy (Bell 1973; Parsons \& Platt 1973); chronic class and ethno-racial conflicts (Bowles \& Gintis 2011 [1976]; Collins 2019 [1979]); or the rise of belief in universal secular knowledge and empowered actorhood (Schofer \& Meyer 2005; Frank \& Meyer 2020). In a synthetic analysis of these architectures, Jackson (2019) laments that "schools, colleges and universities... are treated as black boxes in conventional macro-level theories of expansion" and calls for more sustained attention to organization-level dynamics:

One of the most troubling features of the literature on educational expansion... is the lack of attention to how and why the supply of educational places increases. Sociologists are either silent on these points or they resort to quasi-functionalist narratives in which supply increases 'in response' to demand, with no discussion of the micro-level processes that would lead to new places being added....(15; emphasis original).

This relative inattention to how and why is especially apparent in analyses of the role of government in higher education expansion. Government is a core actor in the theoretical imagery of educational sociology, but government support typically figures as a condition of expansion rather than as something that universities and their leaders actively attempt to cultivate or 
manipulate. Canonical theories of credentialism, for example, recognize government as the essential guarantor of the academic charter and the legal rules requiring academic certifications in particular professions (Collins 1977; Abbott 1988). Sociologists of higher education also recognize the US federal government as a serial funder of higher education: through the Morrill Acts of 1962 and 1890, passed by Congress in efforts to encourage economic development on the western frontier; through myriad contracts with particular universities to train military personnel and provide technical and strategic capacity for fighting World War II; and in the massive investments in applied science and engineering through the Cold War (see Stevens and Gebre-Medhin 2016 for a review). Prior work is clear that the US state regularly seeks educational solutions to social problems (Labaree 2008; Brint 2018:122). But how universities build particular expansion projects around emerging government priorities, and why this activity is temporally and locationally variable, remains a theoretical puzzle.

This puzzle comes into high relief when considering the decades following World War II, when the United States built the largest and most accessible higher education system theretofore in world history. The sheer scale of academic expansion in the postwar US is staggering. Menand (2010:64-65) assembles data from range of sources to summarize:

...between 1945 and 1975, the number of undergraduates increased by almost 500 percent and the number of graduate students increased by nearly 900 percent....In the sixties alone, undergraduate enrollments more than doubled, from 3.5 million to just under 8 million; the number of doctorates awarded every year tripled; and more faculty were hired than had been hired in the entire 325 years of American higher education prior to 1960. 
A copious literature carries the historians' explanatory analogue to sociologists' macro-level forces in explaining this expansion. Historians depict academic leaders as central players in shaping the accretion of government patronage for higher education in the US. They cite various events as drivers of government funding: the legacy of the federal government's utilization of universities to fight World War II and provide veteran reward through the GI Bill (Loss 2012), the Sputnik launch and the evolving geopolitics of the global cold war (Leslie 1993; Lowen 1997; Kaiser 2002), and the political economy of regional growth (Kleinman 1995; O’Mara 2005; Cummings 2017). In these accounts, leaders like Stanford's Frederick Terman leverage local circumstances, institutionalized powers, and historical contingency to accrete advantage for their own organizations. Although these works do not provide a theoretical synthesis of the how and why of postwar higher education expansion on their own, they point toward the possibility of a sociological theory that centers the strategic work of academic actors in particular times and places.

\section{Theorizing Educational Entrepreneurship}

We conceive of educational entrepreneurship as a form of strategic action and a mechanism ${ }^{7}$ for the historical expansion of US higher education. Strategic action consists of "the attempt by social actors to create and maintain stable social worlds" in order to accumulate power (Fligstein \& McAdam 2012:290). A strategic actor promulgates a vision of how power is organized in a field of social activity and tries to convince others to act in alignment with that vision (Bourdieu 1985; Strang \& Meyer 1993; Fligstein 1997; Martin 2003). In practice, strategic actors seek to shift a field in their preferred directions using the specific repertoires of action at their disposal

\footnotetext{
${ }^{7}$ See Gross 2009 on the definition of mechanisms in sociology and their relevance to theories of agency.
} 
(Clemens 1993; Adams 1994). This means that understanding a particular form or instance of strategic action requires attention to the institutional conditions of particular times and places (Clemens 2007, 2015).

Two general features of US higher education create rich conditions for entrepreneurial action. First, universities are hubs: they occupy a structurally central position in the broader US institutional order (Owen-Smith 2018; Stevens et al. 2008). Second, schools possess charters: they are endowed with legitimate authority over the categorization and conferral of official knowledge (Meyer 1970, 1977). Consequently, educational actors enjoy a wide range of potential partners as well as broad latitude to intervene epistemically in social problems (Eyal \& Buchholz 2010). When contingent events disrupt the sense-making routines of collective life elsewhere in society, the organizational and cultural centrality of colleges and universities makes it possible for educational actors to offer academic products and services as solutions to emerging problems.

\section{$H u b$}

Friedland and Alford (1991) posit that societies are composed of multiple institutional fields, each with its own material relations, actor identities, and logics of action. The constant negotiation of terrain among and between these fields catalyzes institutional change (Armstrong \& Bernstein 2008; Panofsky 2014). Overlap among them enables creative action through novel recombinations of institutional materials (Abbott 2005; Padgett \& Powell 2012; Eyal 2013; de Souza Leão \& Eyal 2019). When actors are positioned at the intersection of multiple domains (e.g. family and state) they can leverage relationships and resources across them to their own strategic ends (Padgett \& Ansell 1993). For example, the emergence of the Netherlands as a 
world power in early modern Europe was conditioned by institutionalized gender relations among elite Dutch families and the kinds of political-economic strategies that these relationships could sustain (Adams 1994). The possibility of strategically aligning interests across different domains simultaneously by making "moves in many games at once" (Padgett \& Ansell 1993:1263) is a hallmark of skillful social action generally.

US higher education takes institutional overlap to a remarkable extreme. Colleges and universities transact routinely with all of the other major institutional domains of the modern nation-state: government, the economy, civil society and the private sphere (Stevens et al. 2008). They are "hubs" that connect people, ideas, and resources across domains. Their centrality has some important corollaries. Universities are both physical meeting points and symbolic status markers for professionals and other legitimately knowledgeable elites (Bourdieu 1975; Abbott 2005). In many cases, moving between two social locations obliges one to spend some time in college, and no other route is possible (Owen-Smith 2018). Most societal sectors thus bear some material interest in higher education. Conversely, universities pursue patronage from all of these sectors simultaneously, and their leaders spend a great deal of time building extramural relationships (Cohen \& March 1974). This positional centrality means that universities are often sites of social conflict and creative action.

The interstitial nature of US higher education is important for understanding the role of educational entrepreneurship in broader political and institutional change. The organizational and cultural conditions of the US polity have long mitigated against direct delivery of large-scale social provision from Washington. Elites in government, military, business, and civil society have often relied on universities to translate federal resources into specific projects of welfare, warfare, and statecraft (Mukerji 1989; Loss 2012; Stevens \& Gebre-Medhin 2016). The 
organizational architecture of higher education provides ample flexibility for these projects, which are occasionally "submerged" more or less entirely within colleges and universities (Mettler 2005, 2011). As hubs, universities are especially well-suited to aligning otherwise dissonant interests and projects into joint ventures (Eaton \& Stevens 2020). ${ }^{8}$ This, we will argue, is what Frederick Terman and other academic actors did with alacrity during the middle decades of the twentieth century.

\section{Charter}

Although the institutional centrality of higher education explains why universities are often implicated in broader projects of institutional change, it does not explain what specific things educational organizations are capable of doing that might enable entrepreneurial action. We theorize that this special capacity lies in the academic character of university activities, actors, and outputs. In addition to their practical ties with other societal sectors, universities are central to the organization of meaning in modern societies (Pachucki \& Breiger 2010; Davies \& Mehta 2018; Frank \& Meyer 2020). Their cultural authority extends beyond direct organizational ties and into the making of widely accepted definitions of what is real and true (Starr 1982:13-17; Cetina 1999). Educational institutions define what is knowable and how it is legitimately known, and they authoritatively mark individuals as capable knowers (Meyer 1977). This capacity is what Meyer (1970) called the charter.

Mid-century organizational theorists provocatively described universities as "organized anarchies" (Cohen, March \& Olson 1972). Participants in educational organizations retain

\footnotetext{
${ }^{8}$ There is important kinship here with Clemens' (2020a) analysis of the catalyzing role of non-profit organizations (NPOs) in the US polity generally. Because they are not fully public, private or civic, NPOs are generic mechanisms of what Clemens calls institutional "arbitrage": coordinated collective action across institutional boundaries. We argue that as academic organizations, universities have mechanisms for arbitrage — charters to conduct science and confer academic certifications - that are more or less theirs alone.
} 
distinct and potentially incommensurable interests, and cultivate separate, if often intersecting, lines of action (Weick 1976). The charter is an important source of this anarchic tendency. Schools and the academic professionals they house possess a vast repertoire of readymade cultural artifacts ripe for the production of meaning, few of which are constrained in meaning by any external authority (Bourdieu 1975). Education's distinctive cosmology and the social relationships it scaffolds - populated by students, degrees, certificates, courses, seminars, grades, units, credits, scholarships, departments (etc.) — can provide educational accounts for a wide range of material activities and resource exchanges (Frank \& Meyer 2020). That said, the symbolic flexibility of academic life is not a limitless source of legitimate action. We can learn a great deal about particular episodes of educational entrepreneurship by identifying where would-be entrepreneurs encounter limits to the charter, particularly the distinctive barriers presented by institutional boundaries and local circumstances (Hutt \& Stevens 2017).

\section{Contingency}

In addition to the organizational and cultural centrality of schools, historical events and local circumstances create variably fertile conditions for educational entrepreneurship. By describing historical events as a condition, we mean to highlight the intersubjective quality of time. In all social life, meaning is made from the narration of time's passing and the anticipation of a future to come (Sewell 1996; Mische 2009). Usually, much of this meaning-making activity is routinized into regular sequences of habitual action (Meyer \& Rowan 1977; Swidler 1986; Gross 2009). When events disrupt the ordinary flow of institutionalized interaction, it becomes possible to re-narrate past and present in ways that encourage, legitimate, or even require novel action (Aminzade 1992; Sewell 1996; Emirbayer \& Mische 1998). Understanding how educational 
entrepreneurship unfolds requires investigating how historically situated actors attempt to shape "the construction of futures out of pasts" (Adams, Clemens \& Orloff 2005:9).

Historical events condition educational entrepreneurship in two radically particularistic ways. First, the timing and ordering of events is a core resource for strategic actors in unsettled times. People self-consciously create accounts of unfolding events, endow their accounts with moral authority, and mobilize resources as if they were true (Scott \& Lyman 1968; Sewell 1996; Tilly 2002). This condition clarifies an aspect of strategic action key to understanding educational entrepreneurship. Action is strategic when it entails an active stance toward the passage of time, rather than in the sense of reasoning out a plan in advance. The strategy that ultimately works out in a "successful" case of educational entrepreneurship is more a post facto reflection of how the rules of the game changed than an explanation for how this change was accomplished (Clemens 2015). To be a strategic actor means "standing apart from patterns of regularity and deciding whether to repeat them" (Martin 2003:33) rather than successfully executing a pre-existing causal roadmap. A key ingredient in educational entrepreneurship is the ability to creatively narrate time's passing, and to portray particular forms of education as possessing a special timing, trajectory, or urgency (Clark 1972).

In addition to the timing of events, local circumstances also shape the character and consequences of strategic action (Gould 1991; Sewell 1996). It is not just general institutional configuration that matters; the specific conditions of a place can attenuate or amplify the effects of strategic action. This is why New York City's Stonewall riot was the single event among many altercations between gay bar patrons and police that became a definitive event in history (Armstrong \& Crage 2006); why the San Francisco Bay Area, rather than greater Boston, became the preeminent global hub for the technology industry (Saxenian 1996); and why elites 
in sociologically comparable cities are variably able to build political coalitions and secure economic investment in their communities (Safford 2009; Pacewicz 2016). Educational entrepreneurship similarly implicates the particulars of the place where a school happens to have been founded.

Historical sociologists argue that contingent events create situations where small-scale actions can become consequential determinants of subsequent cascades of change (Sewell 1996; Clemens 2007; Ermakoff 2015). The core argument of this paper is that, within the context of the US polity, schools and their leaders are well-positioned to take advantage of these moments, and also that the particular social locations of schools conditions how their leaders are able to work entrepreneurially in eventful times.

\section{Engineering Education at Stanford during the Cold War}

To put our theorization to the test, we use it to revisit the expansion of engineering education at Stanford University during the Cold War. Data for our empirical inquiry comprise formal organizational records, administrative correspondence, prepared speeches, committee proceedings, reports, publications, and other documents. These materials include a rich collection of Frederick Terman's papers, speeches, memos, and correspondence. ${ }^{9}$ We also make use of archived publications from the Institute of Electrical and Electronics Engineers (IEEE) and its predecessor associations the American Institute of Electrical Engineers (AIEE) and the Institute of Radio Engineers (IRE), as well as materials housed by the United States National Archives, the American Presidency Project, and the John F. Kennedy Presidential Library. In addition to these primary sources, we build on an extensive historiography describing Cold War science at Stanford, a longstanding paradigmatic case for sociologists and historians of science

\footnotetext{
${ }^{9}$ The following abbreviations are used: SUA SC, Stanford University Archives Special Collections.
} 
interested in the contours of the military-industrial-academic complex in the postwar US (Leslie 1993; Geiger 1993; Kleinman 1995; Lowen 1997; O’Mara 2005; Lécuyer 2006; Berman 2012). This body of scholarship makes clear that Stanford's top administrators saw the postwar moment as an opportunity to build what Terman described as "a foundation for a position in the West somewhat equivalent to that of Harvard in the East" (quoted in Leslie 1993:44). In prior historical assessments, Terman's successes are variously attributed to a tradition of porous boundaries between the university and local industry (Saxenian 1996; Lécuyer 2006; Berman 2012); relatively weak faculty governance at the arts-and-sciences core of the university (Geiger 1993; Lowen 1997); and an extensive, coordinated effort to win government funding for research beginning in the 1930s (Leslie 1993; Geiger 1993; Lowen 1997; O’Mara 2005). Yet Terman’s simultaneous entrepreneurship around instruction has received only modest scholarly attention. Reopening this case allows us ask how Terman and his colleagues used Stanford's charter to develop and sustain instructional collaborations across multiple domains simultaneously, and how contingent events and local conditions catalyzed their eventual success.

\section{Courting Industry in Palo Alto before Sputnik}

Terman's efforts to expand engineering education at Stanford were part of a broader project aimed at making the university a premier site for research in the applied sciences. From the perspective of the early postwar period, it was far from obvious how Stanford might pull this off given its great distance from the scientific and manufacturing centers east of the Mississippi River. Yet Terman serially tinkered with the university's degree programs to cultivate connections with an emerging electrical engineering industry in the region south of San Francisco, what eventually became known as Silicon Valley. Notably, industry leaders generally 
did not seek out credentials from Stanford on their own. Terman first had to convince them that high-level academic credentials could be valuable to their businesses.

Terman's earliest documented experiment with Stanford's instructional program was its first doctoral program in electronics. Prior to World War I, doctoral training was uncommon in engineering fields. A retrospective report by Terman on the history of graduate education in electrical engineering (EE) illustrated this point. It counted a mere eleven doctoral degrees conferred in that field between 1900 and 1919. Terman's report also noted that EE faculty at MIT, where Terman earned his own doctorate, had not yet broadly adopted graduate education. In fact, only one faculty member there had earned a doctorate by the 1920s: Vannevar Bush, who had served as Terman's doctoral advisor. ${ }^{10}$ Similarly, when Terman assumed an appointment at Stanford in 1925, he was the first member of the electrical engineering faculty to hold a $\mathrm{PhD}$ (Gillmor 2004).

The early years of Terman's career in Palo Alto were modestly resourced. While Stanford was a relatively wealthy institution by the standards of the time, before World War II it spared few financial resources for radio engineering and electronics. But this area was Terman's core area of expertise, something he believed his fellow electrical engineers needed to pursue more intensively. Their department was thinly staffed, and Terman was tasked with a heavy responsibility for teaching practical skills through lab courses in electronics. Early on, he secured donations of electronic equipment from the US Signal Corps and the Bell System (Gillmor 2004). These donated assets, combined with Terman's close involvement with the postgraduate work of a large proportion of the department's students, emboldened him to make broad and public proclamations about the type of technical training that he believed academic electrical

\footnotetext{
10 Terman, F. E. (1976). “A Brief History of Electrical Engineering Education.” Proceedings of the IEEE 64(9):1399-1407.
} 
engineers should contribute to the field (e.g., Terman 1927). They also marked the beginning of a chain of instructional collaborations with industry.

Terman's early institution-building was sidelined by the start of World War II, but his detour into wartime research work would prove fortuitous. In 1941, Vannevar Bush, who by then was director of the federal Office of Scientific Research and Development, engaged Terman to direct the Radio Research Laboratory (RRL) at Harvard. Terman spent most of the war in Cambridge, overseeing research on signaling, tracking, and electromagnetic countermeasures. RRL's vast human and financial resources provided an education in the power of federal funding. Terman's experience in the Boston hub of wartime R\&D, along with his close ties to Bush, taught him that federal support for research might afford a lucrative way forward in California.

Terman returned west after the war to take the position of Dean of Stanford's School of Engineering. At this point he began an aggressive growth strategy directed at the federal government, as historians of postwar science have amply documented. Though prior scholarly work mentions Stanford's instructional programs only in passing, engineering credentials were central to Terman's growth strategy. His subsequent experiments with the School of Engineering's instructional portfolio reveal a concerted effort to shape Stanford into an appealing recipient of federal support that might otherwise have gone directly to local engineering firms. ${ }^{11}$ To attract government support for engineering science and education, Terman first strove to create relations with industry by convincing them of the business value of advanced academic training.

\footnotetext{
${ }^{11}$ Leslie (1993); Lowen (1997); and O'Mara (2005) all briefly mention HCP and the expansion of graduate training in engineering. However, their analyses focus primarily on the university's efforts to organize R\&D spending around itself; instruction plays only a marginal role in explaining these efforts.
} 
Terman's early instructional experiments are exemplified by the Honors Cooperative Program (HCP), started in 1954 within the Department of Electrical Engineering. HCP allowed locally employed engineers to pursue graduate degrees at Stanford on a part-time basis. By calling it a "cooperative" program, Terman and his colleagues evoked a concept of "cooperative education" well-established in the history of US state-building. Earlier formulations of cooperative education were instantiated in the agricultural extension programs supported by the New Deal at Midwest land-grant universities (Loss 2012), and drew on a longer tradition of cooperative organizational forms in that region (Schneiberg 2007; Schneiberg, King \& Smith 2008; Loss 2012). In engineering co-op programs, students enrolled in university courses at the same time they were pursuing applied work outside the academy. For employers, the key mark of engineering talent was practical experience, which professional engineers viewed as a more important qualification than abstract knowledge (Abbott 1988:92). Describing HCP as an "honors" program lent this populist model a bit of meritocratic cachet. As electrical engineering professor Karl Spangenberg wrote in one of the earliest HCP policy documents, "it is the essence of this program that it is an honors program and that students of exceptional ability will be recruited." 12

What did Stanford mean by "students of exceptional ability"? From the outset, HCP provided a separate admissions pathway for employees at local firms relative to the general applicant pool. Official admissions policy specified that companies seeking to attract skilled employees could sweeten their job offers with a "definite assurance of admission" to Stanford via HCP. Stanford declared three conditions on these assurances. First, employees were required to possess a bachelor's degree from an accredited liberal arts institution, explicitly excluding

\footnotetext{
12 "Working Arrangements For Admission to Stanford of Students on the Honors Cooperative Program in Electronics," 1955, Folder 6, Box 31, Series III, SUA SC 160.
} 
graduates of "trade schools" and "engineering colleges." Second, candidates were to be evaluated by the cooperating company for suitable "personality and character, health and physical condition, age, nationality, etc." Finally, candidates were required to have a "scholastic record...clearly considerably above the minimum" typically required for graduate work. To aid companies in making final determinations in ways Stanford found acceptable, the university confidentially circulated two lists of undergraduate institutions, each with its own grade point average cutoff above which students would be considered adequately qualified. Students from institutions not on these lists were not admitted automatically but instead were individually reviewed "on an expedited basis." As defined by official policy, "exceptional ability" meant possessing an undergraduate pedigree the university deemed adequate.$^{13}$ Beyond that, the companies themselves decided who would participate.

Stanford's leadership framed HCP as a way for employers to draw talent to the West at a time of intensifying federal defense spending and industrial expansion in northern California (Leslie 1993). HCP grew rapidly. By 1957, more than one-third of the graduate students in the School of Engineering were enrolled through the program (Lowen 1997:130). Stanford benefited financially from this arrangement. In addition to individual tuition payments, companies paid an equivalent amount per student as a matching fee to the university. In other words, Stanford received double tuition for each HCP enrollment. ${ }^{14}$ Correspondence between Terman and other administrators shows that these matching funds primarily supported the ambitions of Stanford's engineers, at times disproportionate to their instructional contribution relative to other participating departments. ${ }^{15}$

${ }^{13}$ Ibid.

14 "Honors Cooperative Program in Electrical Engineering, 1957 Situation", 1957, Folder 6, Box 31, Series III, SUA SC 160

${ }^{15}$ A.H. Bowker to F.E. Terman, 1957, "Memo: Analysis of Enrollment of HCP Students.” Folder 6, Box 31, Series III, SUA SC 160. Terman famously justified his systematic favoring of certain departments in matters of administration as "building steeples of excellence" (Leslie 1993:44-75). 
HCP proved effective as a tool for building instructional partnerships with the private sector, but faced additional roadblocks as Stanford's leaders struggled to build instructional partnerships with federal agencies. The university's efforts to build such a partnership with Ames Research Center, a branch laboratory of the federal National Advisory Committee for Aeronautics (NACA), illustrates the ambiguity that characterized these sector-bridging instructional relationships early on. Soon after HCP's inception, Terman began to allow Ames employees to attend Stanford courses on an unofficial basis. By 1956, Ames had 42 employees enrolled at Stanford in courses across the science and engineering disciplines. This number made Ames the largest participant in HCP by a factor of two; the next largest participating employer was Lockheed, with 20 enrollments. ${ }^{16}$ However, the NACA staff were not formally enrolled through HCP, because NACA did not have a mandate to contract with schools for training purposes. This meant that no per-student matching payment to Stanford was possible. The students were enrolled as individuals, and their ability to act as formal ambassadors and enable financial transfers between Ames and Stanford remained limited.

The account in this section has three implications for our theory. First, it demonstrates that educational entrepreneurs can use the charter to build novel cross-sector relationships. Terman took advantage of the university's jurisdiction over academic credentials to define HCP as a solution to industry leaders' recruitment and training problems. Second, it reveals that the explicitly academic character of credentials can be an important part of the entrepreneurial sell. The very name of HCP alluded to prior models of postsecondary education as a project of building civic capacity, and its design enabled participants to be students and company employees simultaneously. Third, it reveals the strategic value of the autonomy afforded to academic organizations in the US polity (Eaton \& Stevens 2020). Terman and his colleagues

\footnotetext{
${ }^{16}$ F.E. Terman. “Companies on Honors Cooperative Program, 1956-57.” Folder 6 Box 31 Series III, SUA SC 160.
} 
were broadly free to shape HCP's admissions policies, fee structures, pedagogical requirements, and overall purposes as they saw fit. The autonomy of the charter creates conditions for entrepreneurial credentialing and incentivizes an ongoing search for clients and patrons.

\section{Attracting Federal Funding in the Wake of Sputnik}

Recall that on the same day that Frederick Terman gave a speech calling for a redirection of national investments in engineering education, the Soviet Union launched Sputnik I into orbit. This event commenced a cascade of political and industrial activity that produced vast new potential patronage for Stanford's engineering credentials. Over the subsequent months and years, Terman mobilized the flexible meaning of engineering education to harness a growing consensus that American science and technology needed rapid improvement. He cannily framed graduate training as the best way that private research universities like Stanford might be enlisted in a global technological arms race, and his colleagues subsequently extended this basic idea into a richly funded network of patrons for Stanford. Terman's educational entrepreneurship reflects how academic leaders take advantage of contingent history.

The federal response to Sputnik involved a comprehensive reorganization of the government's fledgling infrastructure for academic science, much of which would prove immensely beneficial for Stanford's instructional portfolio. President Eisenhower formed his President's Science Advisory Committee (PSAC), a brain trust of academic scientists reporting directly to the President himself, just one month after the launch of the Soviet satellite. Congress passed a $\$ 9$ million supplemental appropriation to the National Science Foundation (NSF) for the expansion of science education programs that year, and the 1959 appropriation to the NSF for 
education included a budget increase of more than 300 percent overall. ${ }^{17}$ The National Defense Education Act (NDEA) formally installed ongoing support for science education as a primary response to Sputnik, offering among other things a new system of graduate fellowships in science and engineering and the first national system of student loans. ${ }^{18}$ As is well documented by others, the administration of federal laboratories and defense research projects underwent its own massive reorganization during this time. NACA was transformed into the National Aeronautics and Space Administration (NASA). In the process of reorganizing its reporting hierarchy, the Department of Defense created the Advanced Research Projects Agency (ARPA) to coordinate its own defense research projects. ${ }^{19}$

Terman quickly recognized that he could leverage these developments to the advantage of Stanford's existing instructional endeavors. The broad policy response of the Eisenhower administration favored a way of building scientific capacity that Terman had long advocated: close cooperation between universities and the defense industry; generous, few-strings-attached funding for graduate training in science and engineering; and increased support for facilities construction at research universities. As O’Mara (2005) has noted, these policies catalyzed particular strategies for regional development that Stanford was uniquely poised to leverage. As early as a meeting of Stanford's trustees convened during the same month as the Sputnik I launch, Terman was describing US science and engineering capacity as a "not too satisfactory situation," a far cry from his previous stance at the Stanford Faculty Club less than two weeks prior. ${ }^{20}$ In July of the following year he remarked that Sputnik had "added fuel to discussions on

\footnotetext{
17 "The Year of the Earth Satellites: The Status of Science and Education in the United States." Eighth Annual Report of the National Science Foundation, January 15, 1959. Retrieved from https://www.nsf.gov/pubs/1958/annualreports/ar_1958_sec2.pdf, last accessed 6 October 2016.

${ }^{18}$ National Defense Education Act of 1958, Pub.L. 85-864.

${ }^{19}$ Department of Defense Reorganization Act of 1958, Pub.L. 85-599

${ }^{20}$ F.E. Terman, notes for a meeting with the Board of Trustees, 17 October 1957; Folder 1, Box 2, Series VIII, SUA SC 160 .
} 
education and increased vastly the audience listening to them." ${ }^{21}$ The construction of a diffuse system of national support for graduate education, in particular, would prove to be an early victory with enduring consequences for Stanford.

Efforts that had begun as tentative experiments before Sputnik took off in its wake. For example, the reorganization of NACA into NASA solidified Stanford's previously tenuous instructional partnership with Ames. Prior to the NASA bill, Ames had been unable to enter into a contractual relationship with Stanford as formal participation in HCP had required. But Section 203(b)(5) of the National Aeronautics and Space Act of 1958 provided NASA laboratories with permission "to enter into and perform such contracts, leases, cooperative agreements, or other transactions...with any person, firm, association, corporation, [or] educational institution." ${ }^{.22}$ In a 1959 memo accompanying a formal contract with Ames, Terman noted that this bill "makes it possible for NASA laboratories, such as the Ames Research Center, to pay educational institutions for instruction of their personnel... [We have] now reached an agreement with them whereby the government will pay Stanford for the full cost of education., ${ }^{23}$ Thus the federal government became a direct funder of engineering education at Stanford.

Stanford's leaders were not uniformly enthusiastic about the terms of federal policy for education under NDEA, viewing them through the lens of their own university's parochial interests. They interpreted the wide-spanning mandate of national student loan aid and NDEA graduate fellowships as so broad that Stanford stood little competitive chance at attracting substantial funding. After corresponding with the federal administrator in charge of NDEA fellowships, Albert H. Bowker (by then Terman's dean of graduate education) communicated to

\footnotetext{
${ }^{21}$ F.E. Terman, "Some Observations on Engineering Education," prepared speech for the Institute of Aeronautical Sciences, 8 July 1958. Folder 2 Box 2 Series VIII SUA SC 160.

${ }^{22}$ National Aeronautics and Space Act of 1958, Pub.L. 85-568.

${ }^{23}$ Contract with NASA Ames, 1959. Folder 6, Box 31, Series III, SUA SC 160 (emphasis original).
} 
Terman that the federal government was likely to support fellowships only in areas where the university did not already have strong graduate programs, such as classics, economics, English, and history. ${ }^{24}$ During later negotiations over proposed federal funding for higher education facilities, Terman reflected his doubt that Stanford would continue to receive substantial support through NDEA. ${ }^{25}$ Faced with competition from the rapidly expanding UC and CSU systems and disadvantaged by its private status, small size, and emphasis on elite science, Stanford evidently did not see itself as a strong contender for these particular streams of federal aid.

Anticipating a future of limited federal funding for Stanford's instructional programs, Terman next worked to influence national policy discourse in ways that invited government support for basic science and advanced training at elite research universities. That spring, serving as a consultant on "Scientific and Technological Manpower" to President Kennedy's iteration of PSAC, Terman authored a report titled "Engineering and Scientific Manpower for the Cold War - The Next Decade. ${ }^{26}$ The report decried the level of national investment in graduate education. It argued that NSF and NDEA graduate fellowships were inadequate to solve the manpower problem, a "token effort relative to the total needs of the nation." Terman was reacting in part to the NSF's growing investments in science education at the high school and undergraduate levels and the comparative lack of growth in graduate fellowships, a strategy Terman had long viewed as misguided. ${ }^{27}$ Instead Terman argued that the best way to quickly

\footnotetext{
${ }^{24}$ A.H. Bowker to F.E. Terman, 2 December 1958. Memo on NDEA fellowships. Folder 9 Box 42 Series III, SUA SC 160.

${ }^{25}$ F.E. Terman, 25 September 1962. Notes on "Facilities Program in Education Bill." Folder 9 Box 42 Series III, SUA SC 160.

${ }^{26}$ F.E. Terman, "Engineering and Scientific Manpower for the Cold War - The Next Decade." Prepared speech for the President's Science Advisory Committee, 21 April 1962. Folder 1, Box 3, Series VIII, SUA SC 160. Terman served as a consultant on PSAC from 1959 to 1963. See also Papers of John F. Kennedy. Presidential Papers. President's Office Files. Departments and Agencies. President's Science Advisory Committee (PSAC): Meeting Manpower Needs in Science and Technology, 9 November 1962. Retrieved from https://www.jfklibrary.org/Asset-Viewer/Archives/JFKPOF-086a-007.aspx, last accessed 7 October 2016.

${ }^{27}$ See e.g. F.E. Terman, "Some Observations on Engineering Education," prepared speech for the Institute of Aeronautical Sciences, 8 July 1958. Folder 2 Box 2 Series VIII SUA SC 160. See also "Program Activities of the
} 
increase scientific manpower in the United States was to invest in those already in the "college pipeline," because expanding admissions would otherwise not result in a growth in the number of $\mathrm{PhDs}$ in science and engineering until after 1970.

The report offered three specific policy changes: (1) immediate, massive, and sustained government expenditure on graduate education in science and engineering; (2) appropriations for additional faculty positions and student research funds; (3) support "on a vastly increased scale" for facilities and equipment to support graduate education and research to match institutional investments one-to-one. Central to his strategy was the idea that "those centers that are presently strong must be used to full capacity, and additionally given every encouragement to expand their capacity.... Fellowships must not be allocated to weak institutions; to do so would be counter to the objective of maximizing the strength of our manpower pool. ${ }^{28}$ To the extent that Stanford had become a "strong institution," there is little question that Terman had Stanford's own fortunes in mind as he forwarded policy recommendations.

Terman's lobbying helped to solidify a funding model among federal science agencies that was favorable to Stanford and other research universities. For example, in a 1963 report, T.L.K. Smull, Director of NASA's Office of Grants and Research Contracts, wrote,

For planning purposes, NASA has set as a goal the production of $1000 \mathrm{PhDs}$ annually.... That a program of this magnitude is necessary has been strongly reinforced by the President's Science Advisory Committee.... This recommends a broad Federal program of support of graduate education and points out the necessity of an increase in FY 64 of approximately 8000 new starts over the 22000 expected in the absence of the program

\footnotetext{
National Science Foundation.” Twelfth Annual Report of the National Science Foundation, January 15, 1963. Retrieved from https://www.nsf.gov/pubs/1962/annualreports/ar_1962_sec2.pdf, last accessed 7 October 2016. ${ }^{28}$ F.E. Terman, "Engineering and Scientific Manpower for the Cold War- The Next Decade."
} 
proposed by the PSAC if the goal that the committee has established of $7500 \mathrm{PhDs}$ per year by 1970 is to be accomplished. ${ }^{29}$

That same year, NASA began funding graduate education in science and engineering through its Sustaining University Program (SUP). Between 1963 and 1967, SUP appropriated nearly \$20 million annually for graduate fellowships, approximately half its total budget. ${ }^{30}$ This represented a tenfold increase from NASA's appropriations for its own training programs just a year earlier. ${ }^{31}$ While only a fraction of NASA's total appropriations for graduate training went to Stanford, the university's successes in lobbying for greater federal funding of advanced science education helped to secure NASA as a robust sponsor of graduate education nationwide.

Terman's efforts to shape national policy on higher education funding after Sputnik I have two implications for our theory. First, they demonstrate that educational entrepreneurs were able to secure government support for educational credentials by defining those credentials as instruments of national security in the wake of what had quickly been defined as a national emergency. Terman and his colleagues leveraged Sputnik for Stanford's own benefit. Their solution to a crisis built on the instructional programs their school already had on offer. Second, Terman's lobbying demonstrates how educational entrepreneurship can inflect the development of the entire field of US higher education, beyond the fortunes of a single school. Terman actively worked to shape how key actors in other domains understood the Sputnik moment, in the hope of directing their attention to the solutions Stanford and institutions like it could offer. His proposals directly influenced funding priorities at federal agencies such as NASA, although

${ }^{29}$ T.L.K. Smull. "NASA Mission: Broaden the University Role." Report, Office of Grants and Research Contracts, National Aeronautics and Space Administration. April 1963. Folder 7, Box 42, Series 3, SUA SC 160.

${ }^{30}$ T.L.K. Smull. "The Nature and Scope of the NASA University Program." Report, Office of Grants and Research Contracts, National Aeronautics and Space Administration. 1965. Also see Geiger (1993), p. 188-190.

${ }^{31}$ F.E. Terman. Notes on NASA manpower program from PSAC manpower committee, 20 April 1962. Folder 5, Box 42, Series 3, SUA SC 160. 
his lobbying efforts toward Congress were themselves at best a mixed success for Stanford. After Congress and the Johnson administration turned their attention toward mass access to postsecondary education after 1963, institutions like Stanford were never again able to attract the disproportionate amounts of federal funding they had received in the years immediately following the Sputnik launch (Geiger 1993).

Stanford was just one player in a rapidly expanding ecology of colleges and universities, and educational entrepreneurs like Terman were active all over the United States. It was the ubiquity and variety of their efforts to secure government funding that made legislation on the scale of the NDEA and HEA both imaginable and politically plausible (Loss 2012). Entrepreneurial activity on the instructional side of the university, parallel and simultaneous to what we depict at Stanford in the 1950s and 60s, is evident throughout the historical record of US higher education, refracted by particulars of physical location and institutional situation.

\section{Variable Conditions for Educational Entrepeneurship}

Educational entrepreneurs work by leveraging instructional programs to build relationships across multiple institutional domains. This variety of strategic action happens throughout the ecology of US higher education, and is refracted through the specific location of schools in the academic field and in the larger national polity. To depict educational entrepreneurship as a general mechanism of US postsecondary expansion, we turn our attention to additional examples. We depict entrepreneurial efforts at Stanford efforts after Terman's tenure, and contrast their trajectory with comparable cases of entrepreneurship in other places and times. These examples reveal how broader institutional conditions - evolving teaching and learning infrastructure (Goldin \& Katz 2009; Loss 2012); heterogeneous styles of regional and municipal 
government (Nations 2018); the racialized character of the US polity generally (Ray 2019) — refract entrepreneurship by shaping the availability of cross-institutional partners and limiting the extensibility of the academic charter.

Stanford's fortunes continued to rise into the 1970s as subsequent generations of leaders honed Terman's approach into a model of regional economic development. Terman trained a cadre of education-oriented engineers who continued to experiment with Stanford's instructional portfolio in subsequent years. In 1969, a group of Stanford engineers led by Joseph M. Pettit, one of Terman's doctoral students and his successor as dean of the School of Engineering, created the Stanford Instructional Television Network (SITN). Citing the logistical challenges of transporting students in the Honors Cooperative Program to and from Stanford's Palo Alto campus during weekdays when HCP students were otherwise obliged to be at work, Stanford constructed an off-campus television transmitter facility capable of beaming courses to locations throughout the Santa Clara Valley, as well as targeted industrial clusters in San Francisco's South of Market neighborhood and around UC Berkeley (see Figure 1). ${ }^{32}$ To support televised instruction, the university also built four hybrid classroom-studios equipped with recording and transmission equipment, and corresponding classrooms to receive the broadcast were built on the campuses of participating companies. The cost of this infrastructure (approximately $\$ 625,000^{33}$ ) was fully borne by HCP member organizations. ${ }^{34}$ SITN deepened Stanford's local network of high-technology firms; 21 organizations already participating in HCP (including Sylvania,

\footnotetext{
${ }^{32}$ Earlier efforts to build educational infrastructure for adults over TV were a mixed success. With extensive organizational and financial support from the Ford Foundation's Fund for Adult Education, a cluster of public universities in the Midwestern United States (particularly the University of Michigan) negotiated favorable FCC regulation in the mid-1950s and built a large educational television network. SITN was created as these earlier efforts were being reorganized into the Public Broadcasting Service (PBS) and built on the technical standards that came out of it, particularly the Instructional Television Fixed Service (ITFS) band. See Loss (2012:150-156); Pettit \& Grace (1970).

${ }^{33}$ On the order of $\$ 4.65 \mathrm{M}$ when adjusted for inflation (2020).

${ }^{34}$ Pettit, Joseph M. and Donald J. Grace. 1970. "The Stanford Instructional Television Network." IEEE Spectrum 7(5), 73-80.
} 
Hewlett-Packard, Lawrence Livermore National Laboratory, and NASA/Ames) built receivers and dedicated classrooms on their own dime in order to participate, and more organizations joined as new enrollment categories became available..$^{35}$

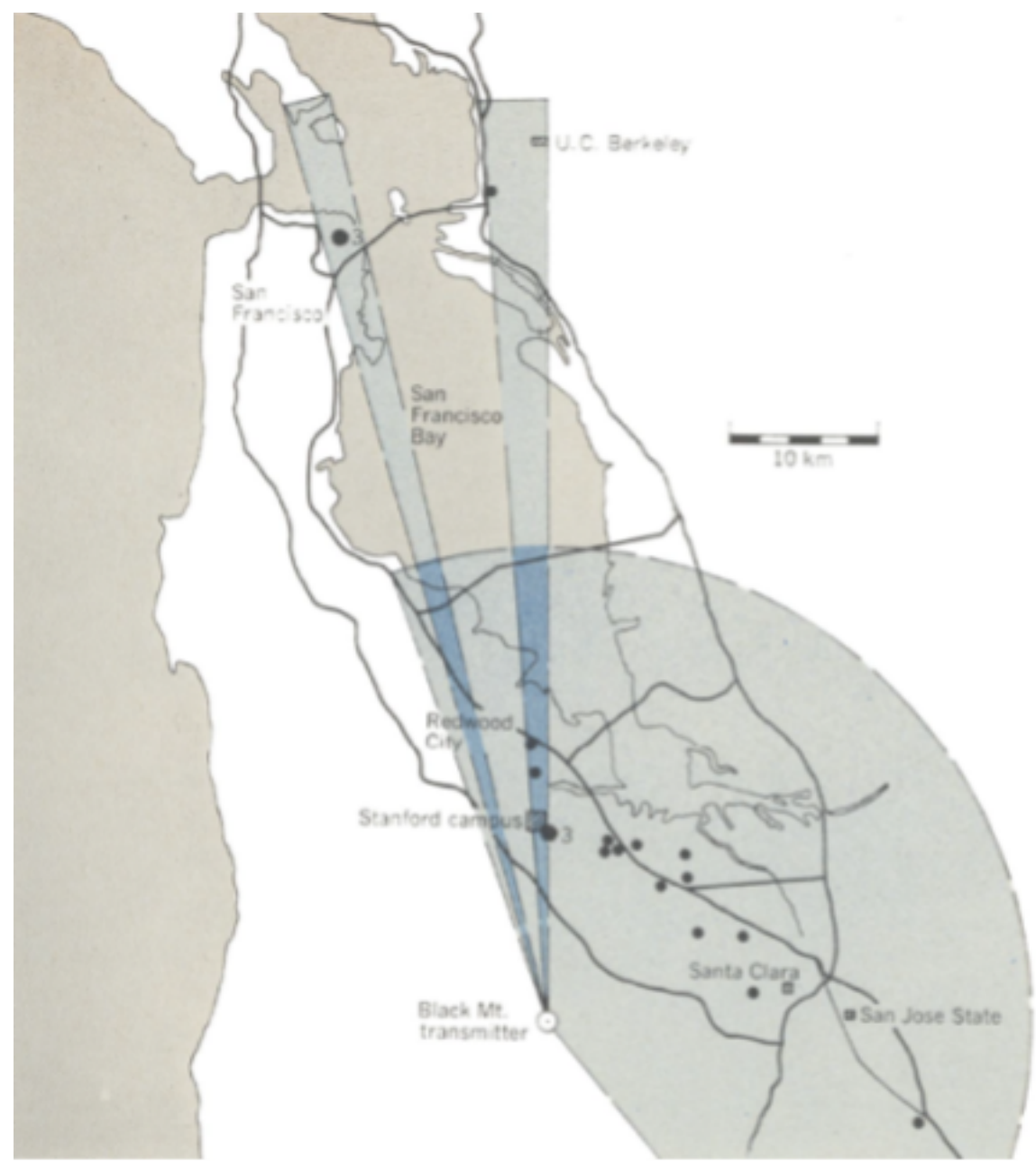

FIGURE 1. Geographic distribu. tion of San Francisco Bay area participants in Stanford instructional television network. Areas in color show approximate coverage of transmitting antennas.

Figure 1. Graphical representation of SITN transmitter range. Black dots represent SITN partner companies, and shaded boxes represent other colleges and universities in the region. Reproduced with original caption from Pettit and Grace (1970).

Stanford's engineers recognized that instructional flexibility beyond the boundaries of a conventional academic degree could be materially advantageous for the university. SITN was designed to yield profits back to the School of Engineering so that it might "expand the faculty,

35 "Report on the Stanford Instructional Television Network. Academic Years, 1969-70 Through 1972-73." 1974. Retrieved from ERIC database (ED087382). Last viewed 21 August 2020. 
broaden the curriculum, and benefit on-campus as well as off-campus students." ${ }^{36}$ SITN offered a range of enrollment options at various price points, including course auditing as well as a "non-registered option" that permitted students to receive a grade for participation in courses without fully enrolling in Stanford through HCP. ${ }^{37}$ They also began offering taped versions of SITN courses by the mid-1970s, allowing SITN to reach beyond its transmission range. ${ }^{38}$ Peer institutions paid for access to SITN facilities and off-peak airtime, further contributing to the enterprise's profitability and extending Stanford's efforts to shape what other colleges and universities were doing. ${ }^{39}$ By 1974, two-thirds of SITN's revenue came from non-degree students, comprising $87 \%$ of course registrations over the network..$^{40}$ Many organizations participated in SITN only because these non-degree options were available without fully committing employees to HCP. ${ }^{41}$ That said, even as they stretched what might count as legitimate instruction, Stanford's engineers adamantly defended their adherence to academic standards: coursework and examinations were graded on campus; remote students were held accountable to Stanford's honor code; and grading standards were set by on-campus enrolled students alone. ${ }^{42}$ Two administrators put it frankly: "[f]rom the university point of view, maintenance of academic standards and image is essential. Under no circumstances can the

\footnotetext{
${ }^{36}$ Morris, Albert J. and Donald J. Grace. 1968. "Conceptual Design of a Television System for Continuing Education." IEEE Transactions on Education 11(3), p. 167.

${ }^{37}$ Pettit, Joseph M. and Donald J. Grace. 1970. "The Stanford Instructional Television Network." IEEE Spectrum 7(5), p. 74.

38 "Report on the Stanford Instructional Television Network. Academic Years, 1969-70 Through 1972-73." 1974. Retrieved from ERIC database (ED087382). Last viewed 21 August 2020.

${ }^{39}$ Morris, Albert J. et al. "Final Report on Cost Effectiveness of Continuing Engineering Studies by Television." American Society for Engineering Education. Retrieved from ERIC database (ED093360). p. 12. Also see Wells, Stuart. 1977. "Cost Analysis of Televised Instruction for Continuing Professional Education." Instructional Science 6(3):259-82.

${ }^{40}$ Morris et al., p. 33, Table 9.

${ }^{41}$ Morris et al., p. 12.

${ }^{42}$ Pettit, Joseph M. and Donald J. Grace. 1970. "The Stanford Instructional Television Network." IEEE Spectrum 7(5):73-80. In particular, write Pettit and Grace (p. 73), "HCP students seldom comprise more than 30 percent of the total class, so there can be no question of their performance establishing the standards for any course."
} 
quality of teaching, courses, or degrees be downgraded." ${ }^{43}$ The capacity of the charter, in other words, was not infinitely flexible. Minding details of campus protocols enabled Stanford to assure clients (and, perhaps also, its own personnel) that these unusually mediated offerings were nevertheless legitimately academic.

Pettit's subsequent career provides an additional example of educational entrepreneurship pursued under markedly different conditions. After Stanford, Pettit went on to serve as president of the Georgia Institute of Technology. An engineering school on the model of MIT, Georgia Tech's mid-century leaders were aware of Stanford's success in transforming federal largesse into a robust regional engineering economy, and hired Pettit in an explicit effort to replicate the Stanford juggernaut (O'Mara 2005:182). But circumstances in Atlanta were not as they were in Palo Alto. Georgia Tech's location in a differently racialized regional political economy brought challenges to expansion that Stanford did not face on its 8,000 acres of ranchland and preponderantly white exurban surround (O'Mara 2005). Civic leaders in Atlanta were divided on what kind of urban growth Georgia Tech should promote, between an older effort to promote white suburbanization and an ascendant Black political movement advocating investment at the urban core. Georgia Tech's alignment with the former mission complicated its implication in city politics and precluded Pettit's ability to reproduce the expansionary tactics that had worked so well on the San Francisco peninsula (O’Mara 2005:183-185). Additionally, Pettit inherited the public Georgia Tech's fraught relationship with the state government, which further limited his ability to negotiate support for intramural academic operations from industry (Geiger 1993:289-292). While Georgia Tech ultimately developed robust research and training programs, it did not become a "Stanford in the South" (Leslie \& Kargon 1996).

\footnotetext{
${ }^{43}$ Morris, Albert J. and Donald J. Grace. 1968. "Conceptual Design of a Television System for Continuing Education." IEEE Transactions on Education 11(3), p. 167.
} 
Conditions for academic entrepreneurship differ markedly between public and private institutions. Because the governance of education is highly localized in the US, state and municipal governments strongly inflect entrepreneurial activity — for better or worse, relative to leaders' goals. For example, during the same years that Terman and his team were experimenting with new patronage models to enrich Stanford's private fortunes, Clark Kerr and his fellows were devising parallel strategies for the proudly public University of California (UC). As with Stanford, Berkeley became a vital component of the Bay Area's Cold War science infrastructure by jointly courting federal contracts and close ties with regional industry (Douglass 2007; Kerr 2001 [1966]). But Kerr and his UC colleagues occupied a different inter-institutional position than their rivals across the bay. Unlike Stanford, UC leadership could also benefit from taxes exacted from California citizens, the ambitions of state politicians, and an emerging system of federal support for broad access to postsecondary education (Rosenbaum 2001). Kerr's signature accomplishment, the 1960 California Master Plan for Higher Education, was a testament not only to his ability to frame UC as a powerful vehicle of public administration and service (Soo \& Carson 2004; Schrum 2019), but also to UC's simultaneous access to the coffers of Washington and Sacramento. California's spectacular public postsecondary system is an outcome of educational entrepreneurship at a particular intersection of regional, state and national polities.

Another example of the political and geographic variability of educational entrepreneurship may be found in the long career of Mordecai Johnson, a theologian who assumed the presidency of Howard University in 1926. Created by an act of Congress and sited in Washington, DC in the wake of the Civil War, Howard singularly positioned its leader for entrepreneurship as a project of social provision. Johnson faced a starkly racialized institutional context for his entrepreneurship. The legacy of slavery and apartheid Howard's founders hoped 
to remediate had long limited the school's capacity to secure private patronage among Black Americans. Howard was further constrained by the stark racialization of the national postsecondary field, a legacy which persists substantially into the present (Miller et al. 2020). Despite these constraints, Johnson enhanced support for Howard by ably wielding the charter. While roundly criticized for accepting greater federal oversight over Howard's affairs, Johnson's ability to garner government funding while strategically defining the campus as a domain of academic freedom made Howard a powerhouse of Black intellectual life (Holloway 2002:47-50). Howard saw huge increases in public and private support during Johnson's thirty-four year tenure. In 1926 the annual federal appropriation for Howard was $\$ 216,000$; in 1960 it was $\$ 7$ million. Substantial private philanthropy, and $\$ 41$ million in additional federal dollars for facilities enhancements, also accrued under Johnson's long watch (Holloway 2002:47). Johnson's success within the context of racialized limitation illustrates both the strategic and situational aspects of educational entrepreneurship.

\section{Discussion and Conclusion}

Sociologists have long recognized educational entrepreneurship as a key driver of US postsecondary expansion, but the conditions and mechanics of this activity have remained undertheorized (Jackson 2019). We build that theory here. Our core insight is that educational entrepreneurship is a special form of strategic action enabled by the institutional centrality and cultural authority of universities. These features of the postsecondary field are powerful assets for academic actors at moments of heightened uncertainty. As ambitious leaders seek to preserve or advance the fortunes of their schools as history unfolds, they variably leverage their social positions and the charter to devise academic solutions to evolving problems. Their success takes 
the form of patronage for universities' core services: academic research and academic credentials. While prior accounts of US educational credential expansion have emphasized the patronage of competing status groups, we have emphasized industry and government as important targets of educational entrepreneurship as well. The US federal government, especially, has been a constitutive source of credential patronage from the middle of the twentieth century forward. Our detailed case study of Frederick Terman's efforts to define the Sputnik 1 launch as a problem for which advanced engineering credentials were solutions exemplifies a nationally distributed phenomenon in which educational entrepreneurs in a variety of contexts (Berkeley, Atlanta, and Washington, DC, among many others) also took advantage of that moment in history to secure government support for academic credentials.

A historicized theory of educational entrepreneurship is a powerful complement to prior sociological accounts of US postsecondary expansion. Existing explanatory narratives — status attainment, status closure, postindustrial modernity, institutional field formation — all betray a paucity of mechanisms. As Jackson (2019:20) summarizes, "[a]n increase in supply cannot straightforwardly occur 'in response to' demand, without institutions and actors as intermediaries and gatekeepers." Our theory locates these intermediaries and gatekeepers in the particular situation of universities in the US institutional order. Contingent history, we theorize, creates variable conditions under which parties outside the academy can be convinced that postsecondary provision can solve their problems. Episodically, particular events create conditions under which the vast resources of the US federal government are at hazard for claim-staking by educational entrepreneurs. Our empirical work on educational entrepreneurship at Stanford at midcentury provides a keyhole glimpse into a diffuse social process through which 
academic leaders have entrenched federal-government underwriting of academic credentials (Starr 2019).

Our theory has two potential scope limitations. First, we devised it to explain postsecondary expansion in the United States: a spectacularly distributed polity whose vast geographic scale, ethnic and racial diversity, and skepticism of centralized government make its institutional fabric globally distinctive (Clemens 2020b). Our theory comes with a US-national parochialism baked in. Cross-national comparative researchers should expect that the mechanics of postsecondary expansion will be different in polities with more centralized states and state-administered education systems, and those in which coordinated collective actions need cross fewer cultural, ethnoracial and regional divides.

Yet it also is the case that academic actors and organizations enjoy at least some measure of autonomy from state authority in nation-states worldwide (Stevens \& Giebel forthcoming). Essential to the power of the academic charter is that it is recognized as universal, granting its holders special privileges to confer credentials and negotiate institutional boundaries in special ways (Willinksy 2017; Frank \& Meyer 2020). We should expect strategic academic actors to leverage the hub and the charter wherever there is money, power or prestige to be gained in doing so. While its empirical expression will be nationally specific, we suspect that our theorization of educational entrepreneurship as a special kind of strategic action has at least some global applicability.

Second, we devised our theorization specifically to understand the swift and dramatic expansion of US postsecondary capacity in the decades immediately following World War II. Our own theory obliges us to recognize the specificity and contingency of that period: when, among other many other conditions, the American people were emboldened by recent wartime 
victory; the United States was newly elevated to the status of a global superpower; and the launch of a 180-pound radio satellite precipitated a national panic. By our own theorization, the material conditions for educational entrepreneurship have changed since then, because historical events and institutional responses to them change social reality.

Those responses are the stuff of textbook history: the National Defense Education Act of 1958 became a policy template for the Higher Education Act (HEA) of 1965, an important component of President Lyndon B. Johnson's Great Society initiative (Graham 1984). Established under HEA's Title IV, federally backed student loans and a means-tested direct cash assistance program (now called Pell Grants) remain omnibus funding streams crucial to the basic operation of the entire US postsecondary sector (Berman \& Stivers 2016; Zaloom 2019). Meanwhile a powerful anti-tax movement, driven in part by white voters' anxieties about the redistributive implications of Great Society and exacerbated by a painful and enduring economic malaise, substantially reduced the capacity of state legislatures to levy taxes in support of massive social provision programs such as public higher education (Self 2005; Martin 2008; Prasad 2018).

These historical changes have not diminished the importance of educational entrepreneurship in US higher education. They merely have changed its conditions. Educational entrepreneurship remains as lively as ever. From the 1980s forward, academic leaders at admissions-selective schools raised their prices, invested heavily in student-lifestyle amenities and in the aesthetic attractiveness of their campuses, elaborated an extensive cadre of temporary and adjunct instructional staff, and increasingly courted affluent out-of-state and international students eager to acquire the cachet of a US credential with an exclusive brand (Hoxby 2009; Kirp 2004). At the other end of the prestige spectrum, schools with essentially open admissions 
have dramatically expanded their client base through online learning. In a business strategy echoing SITN, these latter-day edtech entrepreneurs rely on the web to exploit economies of scale in instructional delivery. While their SITN predecessors took advantage of exploding federal support for engineering technology and the firms that provided it at the height of the Cold War, their contemporary counterparts exploit the loose regulation of Title IV grant and loan disbursement policies to pull Pell grants and federally backed loans through the bank accounts of millions of Americans each year (Cottom 2018).

We have sought to develop a theory that specifies the importance of institutional situation, time and place in the process of postsecondary expansion. To the extent that educational entrepreneurship is a generalizable form of human agency, we expect it to influence the course of history wherever and whenever academic knowledge and credentials are valued assets. At the height of the Cold War, educational entrepreneurs in the United States exploited a national panic and a generous government to build the most productive higher education sector the world had ever seen. But in the second decade of the 21st century, the civic value of postsecondary education is an open question among its foundational patrons. It is no longer clear that the US Congress, federal agencies, or state legislatures view academic institutions as problem-solvers of first resort. The organizational interstitiality and cultural flexibility of academic life persist; whether present or future educational entrepreneurs can secure new resources with claims of public service is an open question. 


\section{References}

Abbott, A. (1988). The System of Professions: An essay on the division of expert labor. Chicago: University of Chicago Press.

Abbott, A. (2005). "Linked Ecologies: States and universities as environments for professions." Sociological Theory 23 (3): 245-274.

Abel, R. L. (1991). American Lawyers. New York: Oxford University Press.

Adams, J. (1994). "The familial state: Elite family practices and state-making in the early modern Netherlands." Theory and Society 23(4):505-539.

Adams, J., E. Clemens, and A. S. Orloff. (2005). Remaking Modernity: Politics, History, and Sociology. Duke University Press.

Aminzade, R. 1992. "Historical Sociology and Time.” Sociological Methods \& Research 20(4):456-480.

Armstrong, E. A., \& Bernstein, M. (2008). "Culture, power, and institutions: A multi-institutional politics approach to social movements." Sociological Theory 26 (1):74-99.

Armstrong, E. A., \& Crage, S. M. (2006). "Movements and memory: The making of the Stonewall myth.” American Sociological Review 71(5):724-51.

Bell, D. (1973). The Coming of Post-Industrial Society: A Venture in Social Forecasting. Basic Books.

Berman, E. P. (2012). Creating the Market University: How Academic Science Became an Economic Engine. Princeton: Princeton University Press.

Berman, E. P. and A. Stivers. 2016. "Student Loans as a Pressure on U.S. Higher Education." Research in the Sociology of Organizations 46:129-160.

Bledstein, B. (1976). The Culture of Professionalism. New York: W. W. Norton \& Co.

Bourdieu, P. (1975). "The Specificity of the Scientific Field and the Social Conditions of the Progress of Reason." Information 14(6): 19-47.

Bourdieu, P. 1985. "The Social Space and the Genesis of Groups." Theory and Society 14(6):723-44. 
Bowles, S. and H. Gintis. (1976). Schooling in capitalist America: Educational reform and the contradictions of economic life. Haymarket Books, 2011.

Brint, S. (2018). Two Cheers for Higher Education: Why American Universities are Stronger than Ever - and How to Meet the Challenges They Face. Princeton: Princeton University Press.

Brint, S. \& Karabel, J. (1989). The Diverted Dream: Community Colleges and the Promise of Educational Opportunity in America. New York: Oxford University Press.

Brown, D. K. (1995). Degrees of control: A sociology of educational expansion and occupational credentialism. Teachers College Press.

Brown, D. K. (2001). “The Social Sources of Educational Credentialism: Status Cultures, Labor Markets, and Organizations." Sociology of Education 74:19-34.

Cetina, K. K. (1999). Epistemic Cultures: How the Sciences Make Knowledge. Harvard University Press.

Clark, B. R. (1972). “The Organizational Saga in Higher Education.” Administrative Science Quarterly 17(2):178-184.

Clark, D. A. (2010). Creating the college man: American mass magazines and middle-class manhood, 1890-1915. University of Wisconsin Press.

Clemens, E. S. (1993). “Organizational repertoires and institutional change: Women's groups and the transformation of US politics, 1890-1920.” American Journal of Sociology 98(4):755-798.

Clemens, E. S. (2007). "Toward a historicized sociology: Theorizing events, processes, and emergence." Annual Review of Sociology 33(1): 527-549.

Clemens, E.S. (2015). “Organizing powers in eventful times.” Social Science History 39(1): $1-24$.

Clemens, E.S. (2020a). "Nonprofits as Boundary Markers: The Politics of Choice, Mobilization and Arbitrage.” Pp. 192-207 in Walter W. Powell and Patricia Bromley, editors, The Nonprofit Sector: A Research Handbook, 3rd edition. Stanford: Stanford University Press.

Clemens, E. S. (2020b). Civic Gifts: Voluntarism and the Making of the American Nation-State. University of Chicago Press. 
Cohen, M. D., \& March, J. G. (1974). Leadership and Ambiguity: The American College President. Cambridge, MA: Harvard Business School Press.

Cohen, M. D., March, J. G. \& J. P. Olsen. (1972). “A Garbage Can Model of Organizational Choice." Administrative Science Quarterly 17(1): 1-25.

Collins, R. (1977). "Some Comparative Principles of Educational Stratification." Harvard Educational Review 47(1): 1-27.

Collins, R. (2019 [1979]). The Credential Society: An Historical Sociology of Education and Stratification. New York, NY: Columbia University Press.

Cottom, T. M. (2018). Lower Ed: The Troubling Rise of For-Profit Colleges in the New Economy. The New Press.

Creager, A. N. H., Lunbeck, E. \& Wise, M. N. (eds.) (2007). Science Without Laws: Model systems, cases, exemplary narratives. Duke University Press.

Cummings, A. S. (2017). “'Brain Magnet': Research Triangle Park and the Origins of the Creative City, 1953-1965." Journal of Urban History 43(3):470-492.

Davies, S. \& Mehta, J. (2018). "The Deepening Interpenetration of Education and Modern Life." Pp. 83-114 in Jal Mehta and Scott Davies (eds.), Education in a New Society. Chicago: University of Chicago Press.

De Souza Leão, L. \& Eyal, G. (2019). “The rise of randomized controlled trials (RCTs) in international development in historical perspective." Theory \& Society 48:383-418.

Douglass, J. A. (2007). The California Idea and American Higher Education. Stanford, CA: Stanford University Press.

Eaton, C., \& Stevens, M. L. (2020). “Universities as peculiar organizations.” Sociology Compass 14(3), e12768.

Emirbayer, Mustafa and Ann Mische. 1998. "What is Agency?” American Journal of Sociology 103(4): 962-1023.

Ermakoff, I. (2014). "Exceptional Cases: Epistemic Contributions and Normative Expectations." European Journal of Sociology 55(2): 223-243.

Ermakoff, I. (2015). “The structure of contingency.” American Journal of Sociology 121(1):64-125.

Eyal, G. (2013). "For a Sociology of Expertise: The Social Origins of the Autism Epidemic." American Journal of Sociology 18:863-907. 
Eyal, G. and L. Buchholz. (2010). "From the Sociology of Intellectuals to the Sociology of Interventions." Annual Review of Sociology 36:117-137.

Fligstein, N. (1997). "Social skill and institutional theory." American Behavioral Scientist 40(4):397-405.

Fligstein, N. \& McAdam, D. (2012). A Theory of Fields. New York: Oxford University Press.

Frank, D.J. and J. W. Meyer. (2020). The University and the Global Knowledge Society. Princeton University Press.

Friedland, R. \& Alford, R. R. (1991). "Bringing society back in: Symbols, practices, and institutional contradictions." In W. W. Powell \& P. J. DiMaggio (eds.), The New Institutionalism in Organizational Analysis: 232-263.

Geiger, R. L. (1993). Research and Relevant Knowledge: American Research Universities since World War II. New York: Oxford University Press.

Gillmor, C. S. (2004). Fred Terman at Stanford. Stanford, CA: Stanford University Press

Goldin, C. D. \& Katz, L. F. (2009). The Race Between Education and Technology. Harvard University Press.

Goldrick-Rab, S. (2016). Paying the price: College costs, financial aid, and the betrayal of the American dream. University of Chicago Press.

Gould, R. V. (1991). "Multiple Networks and Mobilization in the Paris Commune, 1871." American Sociological Review 56:716-729.

Graham, H. D. (1984). The Uncertain Triumph: Federal Education Policy in the Kennedy and Johnson Years. Chapel Hill: The University of North Carolina Press.

Groeger, C. V. (forthcoming). The Education Trap: Schools and the Remaking of Inequality in Boston. Harvard University Press.

Gross, N. (2009). "A pragmatist theory of social mechanisms." American Sociological Review 74(3): 358-379.

Guggenheim, M. \& Krause, M. (2012). "How facts travel: The model systems of sociology." Poetics 40(2): 101-117.

Holloway, J. S. (2002). Confronting the Veil: Abram Harris Jr., E. Franklin Frazier, and Ralph Bunche, 1919-1941. Chapel Hill: University of North Carolina Press.

Hout, M. (2006). "Maximally Maintained Inequality and Essentially Maintained Inequality: Crossnational Comparisons." Sociological Theory and Methods 21(2): 237-252. 
Hout, M. (2012). "Social and Economic Returns to College Education in the United States." Annual Review of Sociology 38: 379-400.

Hoxby, C. M. (2009). “The Changing Selectivity of American Colleges.” Journal of Economic Perspectives 23:91-118.

Hutt, E. L. \& Stevens, M. L. (2017). "From Soldiers to Students: The Tests of General Educational Development (GED) as Diplomatic Measurement.” Social Science History 41:731-755.

Jackson, M. (2019). "Expansion, Enrollment, and Inequality of Educational Opportunity.” Sociological Methods \& Research, online. https://journals.sagepub.com/doi/full/10.1177/0049124119852376

Jencks, C. \& Riesman, D. (1968). The Academic Revolution. New York: Doubleday.

Kaiser, D. (2002). "Cold War requisitions, scientific manpower, and the production of American physicists after World War II.” Historical Studies in the Physical and Biological Sciences 33(1): 131-159.

Kerr, C. (2001 [1966]). The Uses of the University. Cambridge, Mass.: Harvard University Press.

Kirp, D. L. (2004). Shakespeare, Einstein, and the Bottom Line: The Marketing of Higher Education. Harvard University Press.

Kleinman, D. L. (1995). Politics on the Endless Frontier: Postwar Research Policy in the United States. Durham, N.C.: Duke University Press.

Labaree, D. F. (2008). “The Winning Ways of a Losing Strategy: Educationalizing Social Problems in the United States." Educational Theory 58(4): 447-460.

Labaree, D. F. (2018). A Perfect Mess: The Unlikely Ascendancy of American Higher Education. Chicago: University of Chicago Press.

Lécuyer, C. (2006). Making Silicon Valley: Innovation and the Growth of High Tech, 1930-1970. Cambridge, MA: MIT Press.

Leslie, S. W. (1993). The Cold War and American Science: the Military-Industrial-Academic Complex at MIT and Stanford. New York: Columbia University Press.

Leslie, S. W. \& Kargon, R. H. (1996). “Selling Silicon Valley: Frederick Terman's Model for Regional Advantage." The Business History Review 70: 435-472.

Levine, D. O. (1986). The American College and the Culture of Aspiration, 1915-1940. Cornell University Press. 
Levine, E. J. (2016). "Baltimore Teaches, Göttingen Learns: Cooperation, Competition, and the Research University." American Historical Review 121(3):780-823.

Lifschitz, A., M. Sauder, and M. L. Stevens. (2014). "Football as a status system in US higher education." Sociology of Education 87(3): 204-219.

Loss, C. P. (2012). Between Citizens and the State: The Politics of American Higher Education in the 20th Century. Princeton: Princeton University Press.

Lowen, R. S. (1997). Creating the Cold War University: The Transformation of Stanford. Berkeley: University of California Press.

Martin, J. L. (2003). "What is field theory?” American Journal of Sociology 109(1): 1-49. https://doi.org/10.1086/375201

Martin, I. W. (2008). The permanent tax revolt: How the property tax transformed American politics. Stanford University Press.

McLachlan, J. (1970). American boarding schools: A historical study. Scribner.

Menand, L. (2010). The marketplace of ideas: Reform and resistance in the American university. WW Norton \& Company.

Mettler, S. (2005). Soldiers to Citizens: The GI Bill and the Making of the Greatest Generation. New York: Oxford University Press.

Mettler, S. (2011). The Submerged State: How Invisible Government Policies Undermine American Democracy. University of Chicago Press.

Meyer, J. W. (1970). “The Charter: Conditions of Diffuse Socialization in Schools.” Pp. 564-78 In W. Richard Scott, editor, Social Processes and Social Structures. New York: Holt, Rinehart \& Winston.

Meyer, J. W. (1977). “The effects of education as an institution.” American Journal of Sociology 83(1): 55-77.

Meyer, J.W. and B. Rowan. (1977). "Institutionalized organizations: Formal structure as myth and ceremony." American Journal of Sociology 83(2):340-363.

Miller, G.N.S., F. B. Lynn, and L. I. McCloud. (2020). "By Lack of Reciprocity: Positioning Historically Black Colleges and Universities in the Organizational Field of Higher Education." The Journal of Higher Education, online. https://www.tandfonline.com/doi/abs/10.1080/00221546.2020.1803026 
Mische, A. 2009. "Projects and Possibilities: Researching Futures in Action." Sociological Forum 24(3): 694-704.

Mukerji, C. (1989). A Fragile Power: Scientists and the State. Princeton: Princeton University Press.

Nations, J. M. 2018. "Resisting the market university: Political challenges to the locus of authority in public university tuition policy." Social Science History 42(3): 575-600.

Neem, J. N. (2017). Democracy's Schools: The Rise of Public Education in America. Johns Hopkins University Press.

O'Mara, M. P. (2005). Cities of Knowledge: Cold War Science and the Search for the next Silicon Valley. Princeton University Press.

Owen-Smith, J. (2018). Research Universities and the Public Good: Discovery for an Uncertain Future. Stanford: Stanford University Press.

Pacewicz, J. (2016). Partisans and Partners: The politics of the post-Keynesian society. University of Chicago Press.

Pachucki, M. A., and R.L. Breiger. (2010). “Cultural Holes: Beyond Relationality in Social Networks and Culture." Annual Review of Sociology 36(1):205-24.

Padgett, J. F., and C. K. Ansell. (1993). "Robust Action and the Rise of the Medici, 1400-1434." American Journal of Sociology 98:1259-1319.

Padgett, J. F., and W. W. Powell. (2012). The Emergence of Organizations and Markets. Princeton: Princeton University Press.

Panofsky, A. (2014). Misbehaving Science: Controversy and the Development of Behavior Genetics. Chicago: University of Chicago Press.

Parsons, T. and G. M. Platt. (1973). The American University. Cambridge, MA: Harvard University Press.

Prasad, M. (2018). Starving the Beast: Ronald Reagan and the Tax Cut Revolution. Russell Sage Foundation.

Ray, V. (2019). “A theory of racialized organizations.” American Sociological Review 84(1):26-53.

Rosenbaum, J. E. (2001). Beyond College for All: Career paths for the forgotten half. Russell Sage Foundation.

Rudolph, F. 1990. The American college and university: A history. University of Georgia Press. 
Safford, S. (2009). Why the Garden Club Couldn't Save Youngstown: The Transformation of the Rust Belt. Cambridge, MA: Harvard University Press.

Saxenian, A. (1996). Regional Advantage: Culture and Competition in Silicon Valley and Route 128. Harvard University Press.

Schneiberg, M. (2007). "What's on the Path? Path Dependence, Organizational Diversity and the Problem of Institutional Change in the US Economy, 1900-1950.” Socio-Economic Review 5(1): 47-80.

Schneiberg, M., King, M. \& Smith, T. (2008). "Social Movements and Organizational Form: Cooperative Alternatives to Corporations in the American Insurance, Dairy, and Grain Industries." American Sociological Review 73(4): 635-667.

Schofer, E. and J. W. Meyer. (2005). "The worldwide expansion of higher education in the twentieth century." American Sociological Review 70(6):898-920.

Schrum, E. (2019). The Instrumental University: Education in Service of the National Agenda after World War II. Ithaca: Cornell University Press.

Scott, M. B., and S. M. Lyman. 1968. "Accounts." American Sociological Review 33(1): 46-62.

Scott, W.R., and M.W. Kirst. (2017). Higher Education and Silicon Valley: Connected but Conflicted. Baltimore: The Johns Hopkins University Press.

Self, R. O. (2005). American Babylon: Race and the struggle for postwar Oakland. Princeton University Press.

Sewell., W. H., Jr. (1996). "Historical Events as Transformations of Structures: Inventing Revolution at the Bastille." Theory and Society 25:841-881.

Soo, M, \& Carson, C. (2004). "Managing the research university: Clark Kerr and the University of California." Minerva 42:213-236.

Starr, P. (1982). The Social Transformation of American Medicine: The Rise of a Sovereign Profession and the Making of a Vast Industry. New York: Basic Books.

Starr, P. (2019). Entrenchment: Wealth, Power, and the Constitution of Democratic Societies. Yale University Press.

Steffes, T. L. (2012). School, Society, and State: A New Education to Govern Modern America, 1890-1940. University of Chicago Press. 
Stevens, M. L., Armstrong, E. A. \& Arum, R. (2008). "Sieve, incubator, temple, hub: Empirical and theoretical advances in the sociology of higher education." Annual Review of Sociology 34:127-151.

Stevens, M. L. \& Gebre-Medhin, B. (2016). “Association, Service, Market: Higher Education in American Political Development." Annual Review of Sociology 42:121-142.

Stevens, Mitchell L. and Sonia Giebel. Forthcoming. "The Paradox of the Global University." In Sharon Rider, Michael Peters, Mats Hyvönen and Tina Besley (eds.), World Class Universities: A Contested Concept. Singapore: Springer Nature.

Story, R. (1980). The Forging of an Aristocracy: Harvard and the Boston Upper Class, 1800-1870. Wesleyan University Press.

Swidler, A. (1986). "Culture in action: Symbols and strategies." American Sociological Review 51(2): 273-286

Thelin, J. R. (2011). A History of American Higher Education. Johns Hopkins University Press. Tilly, C. (2002). Stories, Identities, and Political Change. Rowman \& Littlefield Publishers.

Torche, F. (2011). "Is a college degree still the great equalizer? Intergenerational mobility across levels of schooling in the United States.” American Journal of Sociology 117(3): 763-807.

Trow, M. (1988). “Higher Education: Past, Present, and Future.” Educational Researcher $17: 13-23$.

Tyack, D. B. (1974). The one best system: A history of American urban education. Harvard University Press.

Wechsler, H. (1977). The Qualified Student: A History of Selective College Admissions. New York: Routledge.

Weick, K. E. (1976). “Educational Organizations as Loosely Coupled Systems.” Administrative Science Quarterly 21:1-19

Willinsky, J. (2017). The Intellectual Properties of Learning: A Prehistory from Saint Jerome to John Locke. University of Chicago Press.

Zaloom, C. (2019). Indebted: How Families Make College Work at Any Cost. Princeton University Press. 